\title{
PEMECAHAN PERMASALAHAN SOSIAL MELALUI PEMBELAJARAN PENDIDIKAN IPS (ILMU PENGETAHUAN SOSIAL) YANG TERINTEGRASI DAN HOLISTIK
}

\author{
Rabini Sayyidati \\ Politeknik Negeri Tanah Laut \\ E-mail: rabini.sayyidati@gmail.com
}

\begin{abstract}
Abstrak
Kajian bersama HISPISI ini merupakan salah satu wujud kepedulian masyarakat Pendidikan IPS untuk mengkaji ulang tentang berbagai permasalahan sosial yang terjadi, khususnya yang berkaitan dengan pembelajaran IPS. Melalui pendidikan IPS yang terintegrasi dan holistik diharapkan peserta didik dapat memecahkan permasalahan sosial yang ada di sekitar lingkungannya. Gambaran cakupan materi ilmu-ilmu sosial dan humaniora adalah berbagai materi yang paling dirasakan penting, bagi kebutuhan pendidikan peserta didik, terutama yang berkaitan dengan pembentukan kemampuan memahami realitas sosial, kemudian peserta didik mampu memberi nilai, baik dalam bentuk internal-personal pribadinya, maupun dalam bentuk eksternal sosial lingkungannya. Selanjutnya, pembelajaran Pendidikan IPS mampu membentuk sikap sosial, yang berlandaskan karakter dan jati diri di lingkungannya, dan terutama sebagai warga masyarakat Indonesia, yang berbudi luhur dan berkepribadian mulia. Seluruh potensi yang terkandung dalam content ilmu-ilmu sosial harus terintegrasi. Oleh sebab itu, pembelajaran Pendidikan IPS yang demikian, diperlukan pemahaman yang luas, bukan saja pada aspek knowledge (pengetahuan), tetapi juga dalam bentuk keterampilan (skill), nilai dan sikap (value and attitude) dan tindakan (action). Melalui 4 dimensi ini, pembelajaran yang terintegrasi dan holistik dapat memecahkan permasalahan sosial yang dilihat dari segala aspek ilmu pendidikan IPS, selain itu juga untuk menumbuhkan pemikiran kritis peserta didik terhadap permasalahan sosial yang ada di lingkungan sekitar mereka.
\end{abstract}

Kata Kunci: Permasalahan Sosial, Pembelajaran, Pendidikan IPS, Terintegrasi, Holistik

\section{PENDAHULUAN}

Era globalisasi ditandai dengan semakin intensnya komunikasi dan informasi di berbagai penjuru belahan dunia, tanpa terbatas jarak dan ruang, serta tidak mengenal batas-batas negara. Kemajuan teknologi dan informasi di Indonesia, bukan saja membawa dampak positif, tetapi juga membawa dampak negatif.

Dampak teknologi informasi dan komunikasi melanda berbagai kalangan di Indonesia. Baik orang tua maupun remaja dan anak-anak. Sisi positif dari kemajuan ini antara lain adalah cepatnya pesebaran berita dari berbagai penjuru dunia, namun mudahnya akses informasi terkadang berdampak negatif, seperti tontonan vulgar maupun berita hoax. Banyaknya provokasiprovokasi yang tersebar lewat media sosial menyebabkan penyimpangan perilaku.

Kalangan pendidikan yang ikut merasa terusik adalah dari HISPISI (Himpunan
Sarjana Pendidikan Ilmu Sosial Indonesia). Masukan Kaji Ulang Mata Pelajaran IPS di SMP/MTs, pada tanggal 29 April 2010, secara jelas menyebutkan berbagai fenomena permasalahan sosial, antaralain; berbagai bentuk pelanggaran dan perilaku tidak tertib. Misalnya, maraknya kenakalan dan perkelahian antar remaja/pelajar, perilaku amoral dan lunturnya budi pekerti, vandalisme, korupsi dan ketidakjujuran, kolusi dan budaya nerabas, anarkisme dan tindak kekerasan, munculnya geng-geng pelajar, penggunaan obat-obatan terlarang dan lemahnya kemandirian serta jati diri bangsa (HISPISI, 2010:1).

Kajian bersama HISPISI ini merupakan salah satu wujud kepedulian masyarakat Pendidikan IPS untuk mengkaji ulang tentang berbagai permasalahan sosial yang terjadi, khususnya yang berkaitan dengan pembelajaran IPS. Hal ini seiring dengan perkembangan teori eksperimental 
pembelajaran, yang berasal dari persoalan sehari-hari (Hill, 2010:1). Namun, realitas aplikasi pembelajaran tidak selalu seiring dengan teori eksperimental tersebut. Salah satu persoalan pokoknya adalah bahwa pendidikan di Indonesia selama ini, cenderung menekankan pada materi ajar, sehingga bersifat intelektualistik (HISPISI, 2010:1). Materi ajar Pendidikan IPS di Indonesia, sebetulnya sangat kaya dengan berbagai informasi kognitif, sehingga ungkapan umum, bahwa untuk menguasai mata pelajaran Pendidikan IPS di persekolahan cukup dengan "rajin membaca", "kuat menghapal", "perbanyak catatan" saja, memberikan "peringatan" kepada kita, untuk mewaspadai "kegagalan" hakekat inti dari tujuan diberikannya mata pelajaran Pendidikan IPS di sekolah.

Dalam implementasi pembelajaran Pendidikan IPS di sekolah, memang sangat tergantung kepada pengetahuan para guru sendiri, terutama dalam memahami tujuan pembelajaran IPS tersebut. Oleh sebab itu, untuk memahami tujuan pembelajaran IPS diperlukan pemahaman mengenai landasan pendidikan IPS.

Dilanjutkan dengan pemahaman konsep-konsep dasar IPS, dan pada gilirannya bagaimana berbagai konsep dasar IPS tersebut, dapat bermanfaat bagi para peserta didik untuk memecahkan permasalahan sosial secara terintegrasi dan holistik. Baik di lingkungan tempat tinggalnya maupun dalam lingkungan yang lebih luas.

\section{TINJAUAN PUSTAKA}

\section{Permasalahan Sosial}

Menurut Jensen dalam Suharto (1997) masalah sosial adalah perbedaan antara harapan dan kenyataan atau sebagai kesenjangan antara situasi yang ada dengan situasi yang seharusnya.

Kemunculan permasalahan sosial menurut Sumarnonugroho (1987) dikarenakan perubahan demografi (pertumbuhan atau pengurangan atau perubahan dalam susunan penduduk), perubahan ekologi (perubahan dalam relasi antara (penduduk dengan lingkungannya), perubahan kultural (perubahan relasi untuk memproduksi hasil ciptaan manusia, termasuk perubahan teknologi, dan perubahan struktur (perubahan organisasi dan relasi sosial).

Perubahan yang alami umumnya tidak banyak mendapatkan sorotan atau tanggapan karena dianggap wajar. Sedangkan perubahan yang terencana sering menimbulkan kritik tajam bila tidak menemukan apa yang diharapkan atau timbulnya masalah sosial akibat tidak sesuainya harapan dan kenyataan.

Seperti yang kita ketahui, salah satu masalah sosial yang masih mengakar di Indonesia adalah kemiskinan. Angka kemiskinan semakin bertambah. Berdasarkan data Badan Pusat Statistik (BPS), rata-rata kenaikan angka kemiskinan di daerah perkotaan di setiap provinsi dari tahun 2013-2017 adalah 0,06\%.

Didukung oleh Itang (2017) yang melakukan studi mengenai faktor penyebab kemiskinan, bahwa di Indonesia jumlah penduduk miskin menurut BPS Pusat terhitung sampai Bulan Maret Tahun 2014 sebanyak 28,28 juta jiwa. Faktor penyebab kemiskinan, yaitu: 1) Pendidikan yang rendah. Tingkat pendidikan yang rendah menyebabkan seseorang kurang mempunyai keterampilan tertentu yang diperlukan dalam kehidupannya. Keterbatasan pendidikan atau keterampilan yang dimiliki seseorang menyebabkan keterbatasan kemampuan seseorang untuk masuk dalam dunia kerja. 2) Malas bekerja. Adanya sikap malas (bersikap pasif atau bersandar pada nasib) menyebabkan seseorang bersikap acuh tak acuh dan tidak bergairah untuk bekerja. 3) Keterbatasan sumber alam. Suatu masyarakat akan dilanda kemiskinan apabila sumber alamnya tidak lagi memberikan keuntungan bagi kehidupan mereka. Hal ini sering 
dikatakan masyarakat itu miskin karena sumberdaya alamnya miskin. 4) Terbatasnya lapangan kerja. Keterbatasan lapangan kerja akan membawa konsekuensi kemiskinan bagi masyarakat. Secara ideal seseorang harus mampu menciptakan lapangan kerja baru sedangkan secara faktual hal tersebut sangat kecil kemungkinanya bagi masyarakat miskin karena keterbatasan modal dan keterampilan. 5). Keterbatasan modal. Seseorang miskin sebab mereka tidak mempunyai modal untuk melengkapi alat maupun bahan dalam rangka menerapkan keterampilan yang mereka miliki dengan suatu tujuan untuk memperoleh penghasilan. 6) Beban keluarga. Seseorang yang mempunyai anggota keluarga banyak apabila tidak diimbangi dengan usaha peningakatan pendapatan akan menimbulkan kemiskinan karena semakin banyak anggota keluarga akan semakin meningkat tuntutan atau beban untuk hidup yang harus dipenuhi.

\section{Pendidikan IPS}

Istilah Ilmu Pendidikan Sosial merupakan terjemahan dari apa yang di dunia pendidikan dasar dan lanjutan di Amerika Serikat dinamakan Social Studies (Daldjoeni, 1981:6). Menurut Sapriya (2009:8) ada beberapa istilah yang lazim diperpustakaan asing yang berkaitan dengan IPS, yaitu: Social Studies, Social Education, Social Studies Education, Social Science Education, Citizenship Education, Studies of Society and Environment. Namun demikian, definisi yang paling berpegaruh berasal dari Edgar Wesley pada tahun 1973, seperti berikut: "The social studies are the social sciences simplified for pedagogical purpose" (dalam Sapriya, 2009:9). Definisi ini, oleh NCSS (National Council for the Social Studies) sebuah lembaga organisasi professional di Amerika Serikat, membuat definisi resmi pada tahun 1993, seperti berikut:

"Social studies is the integrated study of the social sciences and humanities to promote civic competence. Within the school program, social studies provides coordinated, systematic study drawing upon such disciplines as anthropology, archaeology, economics, geography, history, law, philosophy, political science, psychology, religion, and sociology, as well as appropriate content from the humanities, mathematics, and natural sciences. The primary purpose of social studies in to help young people develop the ability to make informed and reasoned decisions for the public good as citizens of a culturally diverse, democratic society in an interdependent world" (Sapriya, 2009:10).

Kiranya, definisi ini sangat lengkap, bahwa: "Pendidikan IPS di Amerika Serikat bersifat integrasi dari ilmu-ilmu sosial dan humaniora untuk meningkatkan kemampuan atau keterampilan warga Negara. Dipergunakan dalam program sekolah, Pendidikan IPS merupakan susunan yang melingkupi yang menggambarkan pembelajaran sistematis dari berbagai disiplin ilmu, seperti; antropologi, arkeologi, ekonomi, geografi, sejarah, hukum, filsafat, ilmu politik, psikologi, agama, dan sosiologi. Sebagaimana sumber seperti isi yang terkandung dalam ilmu humaniora, matematika dan ilmu alam. Keutamaan dari Pendidikan IPS adalah untuk membantu remaja yang sedang berkembang untuk memberikan informasi dan keputusan yang rasional agar menjadi warga masyarakat yang baik dari kultur yang beragam, dalam menghadapi masyarakat demokrasi yang beragam di seluruh dunia".

Dalam konteks Indonesia, Somantri (2001:92) mendefinisikan Pendidikan IPS adalah seleksi dari disiplin ilmu-ilmu sosial dan humaniora, serta kegiatan dasar manusia yang diorganisasikan dan disajikan secara ilmiah dan psikologis untuk tujuan pendidikan.

Berdasarkan definisi diatas, maka yang paling penting adalah melakukan kajian terhadap seluruh materi yang terdapat 
pisikomotorik melalui keterpaduan

dalam ilmu-ilmu sosial dan humaniora, kemudian dibuat sebuah "formula yang khas", sehingga tergambar cakupan materi Pendidikan IPS yang dipergunakan untuk pembelajaran di sekolah. Gambaran cakupan materi ilmu-ilmu sosial dan humaniora adalah berbagai materi yang paling dirasakan penting, bagi kebutuhan pendidikan peserta didik, terutama yang berkaitan dengan pembentukan kemampuan memahami realitas sosial, kemudian peserta didik mampu memberi nilai, baik dalam bentuk internal-personal pribadinya, maupun dalam bentuk eksternal sosial lingkungannya. Selanjutnya, pembelajaran Pendidikan IPS mampu membentuk sikap sosial, yang berlandaskan karakter dan jati diri di lingkungannya, dan terutama sebagai warga masyarakat Indonesia, yang berbudi luhur dan berkepribadian mulia.

Demi membentuk sikap sosial, yang berkarakter dan memiliki jati diri yang berbudi luhur dan berkepribadian mulia, diperlukan landasan Pendidikan IPS, sebagai kerangka pemahaman terhadap berbagai konsep ilmu sosial dan humaniora, dan pada gilirannya berbagai problema sosial di Indonesia dapat diminimalisir.

\section{Terintegrasi}

Terintegrasi yang berasal dari kata integrasi menurut KBBI (Kamus Besar Bahasa Indonesia adalah pembauran hingga menjadi satu kesatuan yang utuh atau bulat.

Dalam dunia pendidikan dikenal dengan istilah pembelajaran terintegrasi atau pembelajaran terpadu. Istilah Pembelajaran Terpadu berasal dari kata integrated teaching and learning atau integrated curriculum approach. Konsep ini dikemukakan oleh Jhon Dewey sebagai usaha untuk mengintegrasikan perkembangan, pertumbuhan, dan kemampuan pengetahuan siswa (Beans dalam Syaefuddin, 2006:4).

Karli (2003:52) menambahkan bahwa pembelajaran terpadu adalah kegiatan yang melibatkan aspek kognitif, afektif dan beberapa mata pelajaran.

Pada pembelajaran IPS terpadu, program pembelajarannya disusun dari berbagai cabang ilmu dalam rumpun ilmu sosial. Pengembangan pembelajaran IPS terpadu dapat mengambil topik dari salah satu cabang ilmu tertentu kemudian dilengkapi, diperdalam dan diperluas dengan cabang-cabang ilmu yang lain. Seperti misalnya topik dengan cabang ilmu Ekonomi, "Pasar bagi Masyarakat" dapat ditinjau dengan cabang ilmu sosial lainnya seperti: ilmu sejarah yang membahas mengenai sejarah pasar, ilmu geografi yang membahas mengenai letak pasar, dan ilmu sosiologi yang membahas mengenai keadaan sosial orang-orang yang saling berinteraksi di pasar.

\section{Holistik}

Holistik dalam pengertian KBBI adalah cara pendekatan terhadap suatu masalah atau gejala, dengan memandang masalah atau gejala itu sebagai suatu kesatuan yang utuh.

Secara yuridis, pola pembelajaran holistik di Indonesia telah diisyaratkan dalam UU No. 20 Tahun 2003 Tentang Sistem Pendidikan Nasional, pada Bab III Pasal 4 ayat 2, ditegaskan bahwa pendidikan diselenggarakan sebagai satu kesatuan yang sistemik dengan sistem terbuka dan multimakna (UU No. 20, 2003:12-13).

Pendidikan dan pembelajaran yang dilaksanakan secara holistik diyakini akan mampu memberikan konstribusi bagi pengembangan potensi peserta didik secara optimal, utuh, dan seimbang serta memberikan makna atau nilai yang bisa dirasakan oleh peserta didik.

Pada sisi lain, Taufik (2011:6-4) mengemukakan bahwa pendekatan holistik dalam pembelajaran diilhami oleh psikologi Gestalt yang dipelopori oleh Wertheirmer, Koffka, dan Kohler. Menurut mereka, objek atau peristiwa tertentu akan dipandang oleh individu sebagai suatu keseluruhan yang 
terorganisasikan. Suatu objek atau peristiwa baru dapat dilihat maknanya jika diamati dari segi keseluruhannya dan keseluruhan itu bukan jumlah bagian-bagian. Sebaliknya suatu bagian baru akan bermakna jika berada dalam kaitan dengan keseluruhan.

Pembelajaran IPS adalah salah satu pembelajaran yang holistik, hal ini didukung oleh Gunawan (2016) yang menyatakan bahwa: Pola pendidikan di Indonesia terbentuk melalui sejarah yang panjang. Dimulai pada jaman HinduBuddha sampai penjajahan Jepang, pola pendidikan yang terbentuk hampir sama yaitu guru dianggap sebagai orang yang sangat dimuliakan karena peran guru diambil oleh kaum Brahmana (jaman Hindu-Buddha), ustad/ajengan (jaman perkembangan agama Islam), pemuka agama Katolik Roma (jaman penjajahan Portugis), tokoh agama Protestan (jaman penjajahan Belanda) dan tokoh pribumi yang dianggap berpengaruh (jaman penjajahan Jepang). Namun pola tersebut sudah tidak dapat diterapkan karena guru bukan satu-satunya sumber informasi pada saat peserta didik belajar. Belajar juga bukan lagi hanya belajar di dalam kelas tapi juga diluar kelas dengan mengembangkan aspek kognitif, afektif dan psikomotor serta soft skills. Merevitalisasikan kembali pembelajaran IPS diperlukan agar peserta didik tidak hanya hapal tapi justru memahami esensi belajar IPS itu sendiri melalui pendidikan yang holistik (menyeluruh). Peserta didik harus tahu bahwa mereka hidup sebagai makhluk sosial yang perlu berinteraksi dengan orang lain. Pendidikan holistik merupakan sebuah perjalanan pendidikan untuk aktualisasi diri dan realisasi diri melalui hubungan dan keterkaitan antara individu, kelompok dan dunia sehingga terintegrasi satu sama lain.

\section{PEMBAHASAN}

Pendekatan terintegrasi dan holistik dalam pembelajaran Pendidikan IPS adalah pendekatan yang sudah seharusnya diterapkan. Dalam fenomena sosial yang penuh dengan permasalahan, diperlukan suatu komitmen kebijakan aplikatif. Seluruh potensi yang terkandung dalam content ilmu-ilmu sosial harus terintegrasi. Oleh sebab itu, pembelajaran Pendidikan IPS yang demikian, diperlukan pemahaman yang luas, bukan saja pada aspek knowledge (pengetahuan), tetapi juga dalam bentuk keterampilan (skill), nilai dan sikap (value and attitude) dan tindakan (action). Keempat ini sering disebut dimensi Pendidikan IPS, yang dapat dijelaskan sebagai berikut:

a. Knowledge (pengetahuan).

Dimensi ini merupakan bagian dasar untuk menjelajah ke tingkat lanjutan. Tahapan ini, telah berkait langsung dengan konsep dasar Pendidikan IPS, yang telah dijelaskan pada bagian sebelumnya. Knowledge hendaknya mencakup; fakta, konsep dan generalisasi. Fakta adalah data yang spesifik tentang peristiwa, obyek, orang dan hal-hal yang terjadi (peristiwa). Misalnya, siswa SMP mengetahui fakta tentang: Mesjid peninggalan Sultan Suriansyah, peristiwa jual-beli di pasar, gunung di Pegunungan Meratus dan lainlain. Konsep merupakan kata-kata atau frase yang mengelompok, berkategori, dan memberi arti terhadap kelompok fakta yang berkaitan. Generalisasi merupakan suatu ungkapan atau pernyataan dari dua atau lebih konsep yang saling terkait (Sapriya, 2009:50).

b. Keterampilan (Skills)

Keterampilan yang harus dimiliki dalam pembelajaran Pendidikan IPS adalah:

(1) Keterampilan meneliti, dimana peserta didik harus pandai mengamati permasalahan sosial yang ada dilingkungan terdekatnya.

(2) Keterampilan berpikir menganalisis masalah sosial-aktual, disini peserta didik mengembangkan kemampuan menganalisisnya sehingga mereka dapat memecahkan dan 
memberikan solusi atas masalah yang mereka temukan.

(3) Keterampilan partisipasi sosial, ikut serta dalam kegiatan lingkungan sekitar. Peserta didik diharapkan dapat meningkatkan sikap tenggang rasa dan kepedulian antar sesama.

(4) Keterampilan berkomunikasi. Melalui komunikasi yang baik, peserta didik dapat menyampaikan ide-ide maupun perasaan mereka terhadap orang lain.

Semua dimensi ini, secara potensial dimiliki oleh para guru yang mengajar dan peserta didik yang belajar. Jika diaktualisasikan dalam pembelajaran, maka proses inquiri dalam pembelajaran Pendidikan IPS akan berjalan dengan baik.

c. Nilai (value) dan Sikap (attitude)

Nilai yang dimaksud adalah seperangkat keyakinan atau prinsip perilaku yang telah memperibadi dalam diri seseorang atau kelompok masyarakat tertentu yang terungkap ketika berpikir atau bertindak. Dimensi ini mencakup nilai:

(1) Nilai Substansial, yakni nilai mendasar yang telah dipegang seseorang karena hasil belajar. Baik bawaan dari keluarga maupun lingkungan sekolah.

(2) Nilai Prosedural, diantaranya: nilai kemerdekaan, toleransi, kejujuran, menghormati kebenaran dan menghargai pendapat orang lain.

d. Tindakan (action), merupakan kunci paling penting dalam menyelesaikan semua permasalahan. Tindakan ini merupakan bentuk nyata dari hasil 3 aspek sebelumnya. Contohnya, jika seorang anak melihat sampah ditengah jalan, ketika ia telah memiliki aspekaspek lainnya maka ia tentu menyadari bahwa hal tersebut bukannlah hal yang baik. Maka tindakan yang dilakukannya adalah memungut sampah itu dan membuangnya ke tempat sampah. Aspek yang lainnya tidak akan terlalu banyak berarti jika aspek tindakan terabaikan.

Berdasarkan realitas permasalahan sosial Indonesia yang demikian kompleks, maka diperlukan Pendidikan IPS yang teritegrasi. Hal ini dapat digambarkan sebagai berikut:

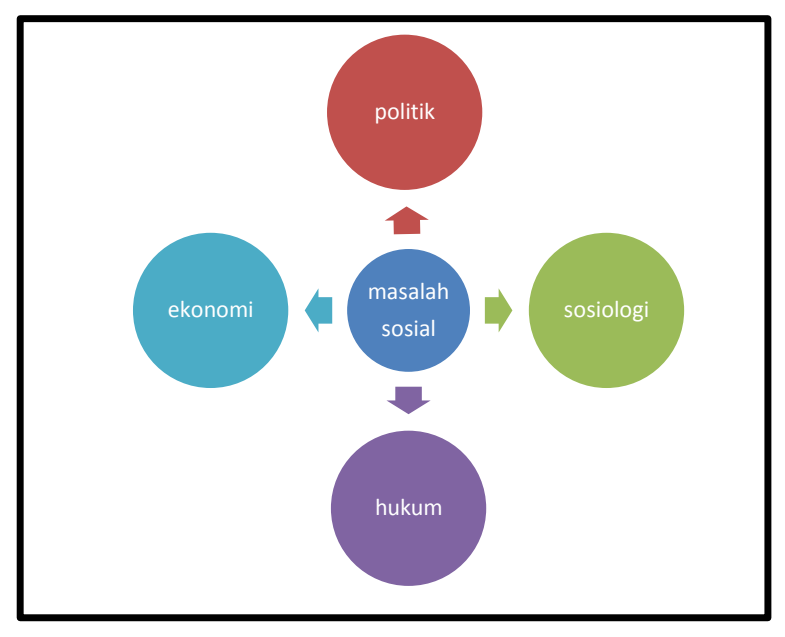

\section{Gambar 1}

Permasalahan sosial merupakan inti kasus, yang diselaraskan dengan materi pembelajaran di sekolah. Pada gambar di atas hanya sekedar contoh melakukan pendekatan terintegrasi dan holistik (Alma, dkk, 2010:23). Integrasi pada gambar di atas bukan hanya politik, ekonomi, sosiologi dan hukum, tentu perlu ditambah lagi dengan sejarah, antropologi, psikologi, geografi, filsafat dan agama. Jika permasalahan sosial itu, digambarkan dalam kerangka dimensi yang harus diaplikasikan dalam pembelajaran, maka dapat digambarkan demikian:

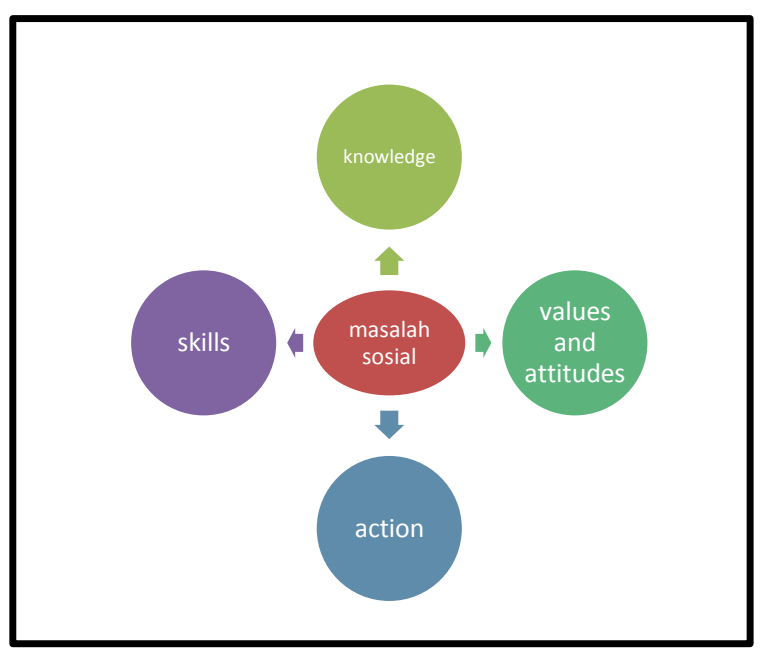




\section{Gambar 2}

Berdasarkan gambar kedua, di atas, maka permasalahan sosial harus ditindaklanjuti dengan konten Pendidikan IPS, yang materinya mutlak harus terintegrasi dan holistik. Hal ini berkenaan dengan wilayah proses belajar yang berbeda. Materi yang disajikan, sesuai dengan standar kompetensi, baik kompetensi dasar, indikatornya yang disesuaikan dengan tema-tema.

Misalnya, pada materi IPS kelas VII, kompetensi dasarnya adalah menganalisis kondisi alam dan batas wilayah kepulauan Indonesia untuk melatih berpikir kritis, menumbuhkan rasa bangga terhadap kekayaan dan keindahan alam Indonesia, mengenali batas-batas negaranya, sehingga terdorong untuk melestarikan dan mempertahankannya, serta memiliki rasa bangga dan percaya diri.

Indikatornya; 1) Mendeskripsikan keadaan alam Indonesia. 2) Menunjukkan batas-batas wilayah Kepulauan Indonesia (lintang dan bujur maupun kontinen). 3) Menumbuhkan kecintaan terhadap kekayaan dan keindahan alam Indonesia. Pada materi ini dapat diberikan uraian yang tersaji melalui buku atau penjelasan guru.

Selanjutnya, untuk menumbuhkan sikap kritis peserta didik pada permasalahan sosial di lingkungan masing-masing. Sebagai contoh, masalah yang biasa muncul antara lain: sampah di sungai, penggundulan hutan, tambang liar, disiplin berlalu lintas, perusakan fasilitas umum, dan lain-lain. Jika kita mengambil sampah di sungai sebagai inti masalah, maka materi sajian dapat ditinjau secara terintegrasi dan holistik, sebagai berikut:

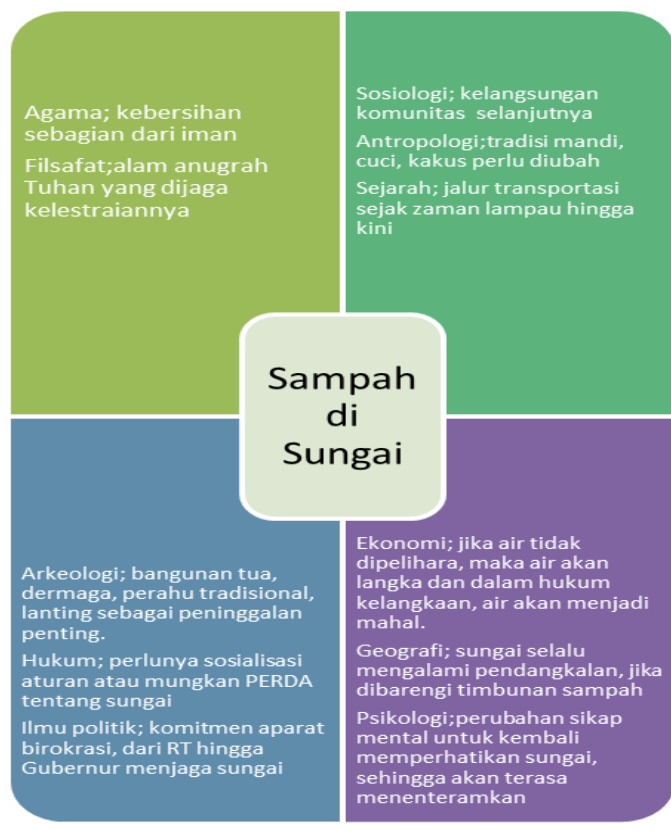

\section{KESIMPULAN}

Berdasarkan bahasan di atas, maka dapat disimpulkan sebagai berikut:

1. Permasalahan sosial dapat dipecahkan dengan Pendidikan Ilmu Pengetahuan Sosial dengan pendekatan yang terintegrasi dan holistik.

2. Pendidikan IPS harus mengedepankan daya kritis untuk memecahkan permasalahan sosial dari segala dimensi.

3. Aplikasi pembelajaran Pendidikan IPS meliputi 4 dimensi yaitu: knowledge, skills, value and attitude, dan action.

\section{DAFTAR PUSTAKA}

Alma, Buchari, dkk. 2010. Pembelajaran Studi Sosial. Alfabeta. Bandung.

Al Muchtar, Suwarma. Visi dan Misi pendidikan IPS Dalam Perspektif Perubahan Sosial Budaya. MakalahSeminar dan lokakarya Kuliah Perdana Program studi Magister Pendidikan IPS FKIP UNLAM. Banjarmasin, 6 Maret 2010.

Daldjoeni. N. 1981. Dasar-Dasar Ilmu Pengetahuan Sosial. Alumni. Bandung.

Gunawan, Rudy. 2017. Pendidikan Holistik dalam Pembelajaran IPS di SMP/MTS. in: Pendidikan Holistik Konsep dan Implementasi dalam Pendidikan. Jakarta: Uhamka Press. 
Hill. Winfred F. 2010. Theories of Learning. Teori-teori Pembelajaran ,Konsepsi, Komparasi dan Signifikansi. Penerbit Nusa Media. Bandung.

HISPISI. 2010. Pendidikan IPS (definisi, tujuan, SKL, konten, proses dan asesmen). Makalah. Yogyakarta.

https://www.bps.go.id/publication.html

ITANG, Itang. Faktor Faktor Penyebab Kemiskinan. Tazkiya, [S.1.], v. 16, n. 01, p. 1-30, Jan. 2017.

Kamus Besar Bahasa Indonesia. Diakses melalui kbbi.web.id pada tanggal 17 September 2017.

Karli, H. Dan Yuliatiatittingsih. 2003. ModelModel Pembelajaran. Bina Media Informasi. Bandung.

Sapriya. 2009. Pendidikan IPS. PT. Rosdakarya. Bandung.

Somantri, Nu'man. 2001. (Editor: Dedi Supriadi \& Rahmat Mulyana). Menggagas Pembaharuan Pendidikan IPS. Bandung. PPS-FPIPS UPI dan Remadja Rosda Karya.

Suharto, Edi. 1997. Pembangunan, Kebijakan Sosial dan Pekerjaan Sosial: Spektrum Pemikiran, Lembaga Studi Pembangunan-STKS. Bandung.

Sumarnonugroho, T. 1987. Sistem Intervensi Kesejahteraan Sosial. Hanindita. Jogjakarta.

Saud, Udin Saefudin. 2006. Perencanaan Pendidikan Suatu Pendekatan Komprehensif. Rosdakarya. Bandung.

Suprijono, Agus. 2009. Cooperative Learning, Teori dan Aplikasi PAIKEM. Pustaka Pelajar. Jogyakarta.

Taufik, Agus, dkk. 2011. Pendidikan Anak di $S D$. Universitas Terbuka. Jakarta.

UU No. 2 Tahun 2003. 2003. Tentang Sistem Pendidikan Nasional dan Penjelasannya. Media Wacana Press. Jogjakarta. 